\title{
A STUDY OF CORRELATION OF CLINICAL RESPONSE WITH MICROBIOLOGICAL SENSITIVITY IN COPD PATIENTS WITH ACUTE EXACERBATION
}

\author{
D. Seshagiri Rao ${ }^{1}$, P. Surya Kiran ${ }^{2}$ \\ 1 Professor, Department of Pulmonary Medicine, Guntur Medical College. \\ 2Postgraduate Student, Department of Pulmonary Medicine, Guntur Medical College.
}

\section{ABSTRACT}

\section{BACKGROUND}

The purpose of this study is to correlate the clinical outcome in patients of COPD with acute exacerbation with the bacteriology and culture sensitivity of the pathogens.

\section{MATERIALS AND METHODS}

This is a prospective study done in Government Fever Hospital/Guntur Medical College, Guntur from January 2014 to June 2015. The total number of patients included in the study was 100. Out of 100 patients, 94 (94\%) were males and $6(6 \%)$ were females. The mean age of the patients in this study was 56.8 years. The youngest patient was 39 years old and the oldest patient was 80 years old, giving an age range of 39 to 80 years. The study group consisted of patients already diagnosed as COPD who were admitted in Government Fever Hospital/Guntur Medical College, Guntur with features suggestive of acute exacerbation of COPD during the period from January 2014 to June 2015. The procedure workup consists of detailed clinical history along with chest $\mathrm{x}$ ray PA view. If both of them satisfied the inclusion and exclusion criteria, then routine blood investigations including $\mathrm{Hb} \%$, $\mathrm{RBC}$ count, TLC and DLC are done and sputum is collected in a wide mouthed sterile sputum container.

\section{RESULTS}

The procedure workup consists of detailed clinical history along with chest x-ray PA view. If both of them satisfied the inclusion and exclusion criteria, then routine blood investigations including $\mathrm{Hb} \%$, RBC count, TLC and DLC are done and sputum is collected in a wide mouthed sterile sputum container.

\section{CONCLUSION}

Present study concludes that bacteria are major cause for AECOPD as bacteria were cultured in 92\%. Sputum Gram stain examination gives immediate result, is a simple, reliable bed side tool in identifying the causative bacteria for AECOPD and also correlates with sputum cultures. Purulent sputum is an indication to initiate antibiotic therapy. The commonest bacteria isolated are Streptococcus pneumoniae (28\%) followed by Klebsiella pneumoniae (20\%). A control group of 20 patients with AECOPD have been selected and were initiated empirical antibiotic therapy without sputum examination for bacteriology. The result of clinical response have been studied. The present study also concludes that either oral or parenteral ampicillin will not benefit patients with bacterial cause of AECOPD. Quinolones and aminoglycosides are more effective in treating the bacterial exacerbation of the chronic obstructive pulmonary disease.

\section{KEYWORDS}

Acute Exacerbation of COPD (AECOPD), Culture Sensitivity, Gram Staining, Sputum Examination, Treatment Response in Patients with AECOPD.

HOW TO CITE THIS ARTICLE: Rao DS, Kiran PS. A study of correlation of clinical response with microbiological sensitivity in COPD patients with acute exacerbation. J. Evolution Med. Dent. Sci. 2017;6(1):56-61, DOI: 10.14260/Jemds/2017/15

\section{BACKGROUND \\ An exacerbation of the COPD is an acute event characterised by worsening of the patient's respiratory symptoms that is beyond normal day-to-day variation and lead to change in medication.(1) Exacerbation of COPD is important because it is associated with significant mortality, negatively affects the patient's quality of life and accelerates the decline in lung function. Exacerbations can be precipitated by the several risk factors. Clinical features of acute infection in}

Financial or Other, Competing Interest: None.

Submission 25-11-2016, Peer Review 20-12-2016,

Acceptance 26-12-2016, Published 02-01-2017.

Corresponding Author:

Dr. D. Seshagiri Rao,

\#1-9-23, Sreeramnagar,

Kakinada, Andhra Pradesh,

India.

E-mail: drdsraosai@gmail.com

DOI: $10.14260 /$ jemds $/ 2017 / 15$
COPD include increased dyspnoea, productive cough. There may be fevers, chills, malaise, pleural chest pain and haemoptysis. The sputum's colour or thickness may change. It is difficult to diagnose 33 respiratory infections in a patient with AECOPD, because many of the symptoms and signs are present at baseline or can be seen in non-infectious exacerbations.

Chest x-ray should be taken to exclude alternative diagnosis. Spirometry should not be done to the patient with exacerbation, because the result is inconclusive and the patient has poor general condition. Haemogram, pulse oximetry, arterial blood gas analysis and electrocardiogram should be obtained to assess the severity of the exacerbation. Treatment of the exacerbation include increase in frequency and dose of inhaled or nebulised short-acting bronchodilators, either beta- 2 agonists or anticholinergics. Intravenous methylxanthines may be used as second line agents. Corticosteroids improve lung function and shorten the recovery time. 
Antibiotics should be given to patients with all the cardinal signs of increase in dyspnoea, purulent sputum and copious amounts of expectoration. Selection of the antibiotic depends on local resistance pattern of the bacteria. Usual duration of the treatment is 5 - 10 days.(2) Supplemental oxygen therapy, non-invasive or invasive ventilation should be considered in every patient with respiratory distress. Exacerbations can be prevented by protective measures against air pollution, cessation of smoking, pneumococcal and influenza vaccination in elderly and low mobility or poor reflexes like in Parkinson's disease or residual stroke. Use of phosphodiesterase-4 inhibitors like roflumilast has also been proposed. Knowledge about use of current medication and inhalation technique are vital in prevention of exacerbations. $(3,4)$ The risk of death from an exacerbation of COPD is closely related to the development of respiratory acidosis, the presence of serious co-morbidities and the need for ventilatory support. Patients without these features are not at high risk of death, but those with severe underlying COPD often require hospitalisation. ${ }^{(5)}$

\section{Aims}

1. To identify the specific pathogens causing an acute exacerbation in patients with previously diagnosed COPD patients in a cohort of 100 patients.

2. To correlate the clinical response in patients with AECOPD in study group with similar patients selected as control group.

\section{Inclusion Criteria}

Patient previously diagnosed as COPD having at least two of the following three symptoms were included in the study.

1. Increase in dyspnoea.

2. Increase in sputum production.

3. Increase in purulence of sputum.

\section{Exclusion Criteria}

1. Received antibiotics in the past four weeks.

2. Patients with infiltrates in chest $x$-ray.

3. Patients of cystic fibrosis, bronchiectasis, tuberculosis or other lung disease.

4. Sputum microscopy specimen with $>10 \%$ epithelial cells per low power field and $<25$ polymorphs per low power field were not cultured.

\section{MATERIALS AND METHODS}

1. Disposable and sterilised wide mouthed sputum container.

2. Glass slides, 2 in number.

3. Nichrome loop wire and spirit lamp.

4. Sheep blood agar and McConkey plate.

5. Stains used in Gram's staining technique.

6. Antibiotic discs.

\section{Methodology}

\section{Sputum Collection}

The patient is advised to collect the sputum in wide mouthed sterile container provided at the time of admission. And this sputum container is transported to the Department of Microbiology, Guntur Medical College within half an hour.

\section{Sputum Examination}

In the Department, direct microscopy of the smear prepared from the sputum transported is examined under low power field of the microscope. If the smear has $<10$ epithelial cells and $>25$ pus cells under low power field, then sputum inoculation is done.

\section{Sputum Inoculation}

One loop full of specimen is inoculated on to the surface of a well dried sheep blood agar plate and McConkey plate. The inoculum is distributed on the plates by a method called "surface plating" (technique streak culture). The streak culture technique consists of transferring the inoculum on to the surface of a well dried plate, on which it is spread over a small area at the 37 periphery. The inoculum is then distributed thinly over the plate by streaking it with the loop in series of parallel lines in different segments of the plate.

After inoculating the plates, Gram's staining is performed on the smear prepared from the sputum sample.

After incubating the plates at $37^{\circ} \mathrm{C}$ for $24 \mathrm{hrs}$., the colony characteristics on the inoculated plates were noted.

\section{Colony Confirmation}

The colonies obtained from the blood agar plate were confirmed by Gram staining.

The McConkey plate was also incubated overnight at $37^{\circ} \mathrm{C}$ and if there was any growth the colony characteristics were studied by Gram's Method and further confirmation was made by biochemical reactions (IMViC reactions and sugar fermentation).

\section{Antibiotic Sensitivity Testing}

By Modified Kirby-Bauer method, it was done by disc diffusion technique on Mueller Hinton agar.

\section{Statistics}

This is a prospective study done in Government Fever Hospital/Guntur Medical College, Guntur from January 2014 to June 2015. The total number of patients included in the study was 100 .

\section{Sex Distribution}

Out of 100 patients 94 (94\%) were males and $6(6 \%)$ were females.

The mean age of the patients in this study was 56.8 years. The youngest patient was 39 years old and the oldest patient was 80 years old, giving an age range of 39 to 80 years. The following Table 7 and Figure 4 gives the age distribution of the patients in this study.

This is a prospective study done in Government Fever Hospital/Guntur Medical College, Guntur from January 2014 to June 2015. The total number of patients included in the study was 100 .

\section{Demographic Data \\ Sex Distribution}

Out of 100 patients 94 (94\%) were males and $6(6 \%)$ were females.

\section{RESULTS}

An exacerbation of the COPD is an acute event characterised by a worsening of the patient's respiratory symptoms that is beyond normal day-to-day variation and lead to change in medication. Exacerbation of COPD is important because it is associated with significant mortality, negatively affects the patient's quality of life and accelerates the decline in the lung function. Exacerbations can be precipitated by several risk factors, mainly smoking and old age. 
Antibiotics should be given to patients with all the cardinal signs of increase in dyspnoea, purulent sputum and copious amounts of expectoration. Selection of the antibiotic depends on local resistance pattern of the bacteria. Usual duration of the treatment is 5 - 10 days. Supplemental oxygen therapy, non-invasive ventilation should be considered in every patient with respiratory distress. Exacerbations can be prevented by protective measures against air pollution, cessation of smoking, pneumococcal and influenza vaccination in elderly and low mobility or poor reflexes like in Parkinson's disease or residual stroke. Aim of study is to identify the specific pathogens causing an acute exacerbation in patients with previously diagnosed COPD patients in a cohort of 100 patients. To correlate the clinical response in patients with AECOPD in study group with similar patients selected as control group.

The patient is advised to collect the sputum in wide mouthed sterile container provided at the time of admission. And this sputum container is transported to the Department of Microbiology, Guntur Medical College within half an hour. Meanwhile start antibiotics and wait for culture sensitivity, and we can change antibiotic accordingly to check clinical improvement.

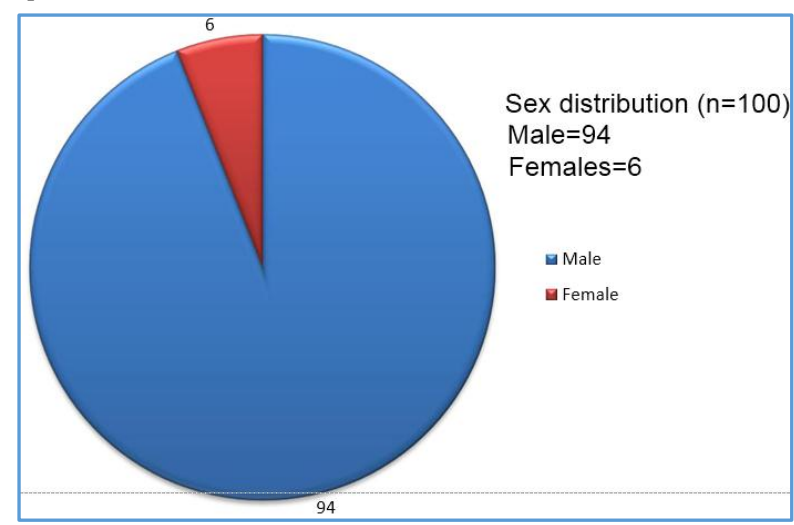

Figure 1. Sex Distribution

Age Distribution

The mean age of the patients in this study was 56.8 years. The youngest patient was 39 years old and the oldest patient was 80 years old, giving an age range of 39 to 80 years. The following Table 1 gives the age distribution of the patients in this study.

\begin{tabular}{|c|c|c|}
\hline Age & No. of Cases & Percentage of Total Cases (\%) \\
\hline $31-40$ & 4 & 4 \\
\hline $41-50$ & 28 & 28 \\
\hline $51-60$ & 36 & 36 \\
\hline $61-70$ & 20 & 20 \\
\hline $71-80$ & 12 & 12 \\
\hline Total & $\mathbf{1 0 0}$ & $\mathbf{1 0 0}$ \\
\hline \multicolumn{3}{|c|}{ Table 1. Age Distribution } \\
\hline
\end{tabular}

\section{Risk Factor Evaluation}

$64(64 \%)$ out of 100 patients of this study were current smokers, $28(28 \%)$ patients were ex-smokers and $8(8 \%)$ were non-smokers. All the females were non-smokers. Exposure to biomass fuel was present in all the female patients.

\begin{tabular}{|c|c|c|c|}
\hline No. of Patients & \multicolumn{3}{|c|}{ Smoking Pattern } \\
\hline \multirow{2}{*}{100} & Smokers & Ex-Smokers & Non-Smokers \\
\cline { 2 - 4 } & $64(64 \%)$ & $28(28 \%)$ & $8(8 \%)$ \\
\hline \multicolumn{3}{|c|}{ Table 2. Smoking Pattern of Study Population } \\
\hline
\end{tabular}

\section{Symptoms}

The most common symptom is cough with expectoration $(100 \%)$.

\begin{tabular}{|c|c|c|}
\hline Symptom & No. of Cases & Percentage (\%) \\
\hline Cough & 100 & $100 \%$ \\
\hline Expectoration & 100 & $100 \%$ \\
\hline Breathlessness & 95 & $95 \%$ \\
\hline Fever & 52 & $52 \%$ \\
\hline Chest pain & 24 & $24 \%$ \\
\hline \multicolumn{3}{|c|}{ Table 3 } \\
\hline
\end{tabular}

\section{Sputum}

The most common type of sputum obtained is mucopurulent in $80(80 \%)$ patients followed by mucoid in $20(20 \%)$ patients.

\begin{tabular}{|c|c|c|c|}
\hline Type of Sputum & Cases & Total Cases & Percentage \\
\hline Mucopurulent & 80 & 100 & $80 \%$ \\
\hline Mucoid & 20 & 100 & $20 \%$ \\
\hline \multicolumn{3}{|c|}{ Table 4. Sputum Microscopy } \\
\hline
\end{tabular}

\begin{tabular}{|c|c|c|c|}
\hline Type of Sputum & Cases & $\begin{array}{c}\text { Isolation } \\
\text { of Bacteria }\end{array}$ & $\begin{array}{c}\text { Percentage } \\
\text { Positivity (\%) }\end{array}$ \\
\hline Mucopurulent & 80 & 80 & 100 \\
\hline Mucoid & 20 & 12 & 60 \\
\hline Table 5. Bacterial Isolation from the Sputum Culture \\
\hline
\end{tabular}

\begin{tabular}{|c|c|c|c|}
\hline Bacterial Growth & Cases & Total Cases & Percentage (\%) \\
\hline Positive & 92 & 100 & 92 \\
\hline Negative & 8 & 100 & 8 \\
\hline \multicolumn{2}{|c|}{ Table 6. Bacterial Growth in Sputum } \\
\hline
\end{tabular}

\begin{tabular}{|c|c|c|}
\hline $\begin{array}{c}\text { Gram Staining } \\
\text { Technique }\end{array}$ & $\begin{array}{c}\text { Culture Positive in } \\
\text { Correlation } \\
\text { with Gram Stain }\end{array}$ & $\begin{array}{c}\text { Percentage } \\
\text { Positivity }\end{array}$ \\
\hline Bacteria identified - 76 & 76 & $100 \%$ \\
\hline $\begin{array}{c}\text { No bacteria identified - } \\
\text { 24 }\end{array}$ & 16 & $66.67 \%$ \\
\hline \multicolumn{2}{|c|}{ Table 7. Comparison of Gram Stain and Culture } \\
\hline
\end{tabular}

\begin{tabular}{|c|c|c|}
\hline Bacteria identified & 8 & $40 \%$ \\
\hline No bacteria identified & 12 & $60 \%$ \\
\hline $\begin{array}{c}\text { Table 8. Gram Stain Technique of Mucoid Sputum Gram } \\
\text { Stain Technique of Mucoid Sputum (20) }\end{array}$ \\
\hline \multicolumn{2}{|c|}{} \\
\hline \multicolumn{2}{|c|}{} \\
\hline
\end{tabular}

\begin{tabular}{|c|c|c|}
\hline Bacteria identified & 68 & $85 \%$ \\
\hline No bacteria identified & 12 & $15 \%$ \\
\hline Table 9. Gram Stain Technique of Mucopurulent Sputum \\
Gram Stain Technique of Mucopurulent Sputum (80) \\
\hline
\end{tabular}

\begin{tabular}{|c|c|c|c|}
\hline $\begin{array}{c}\text { Total } \\
\text { No. }\end{array}$ & $\begin{array}{c}\text { Bacteria } \\
\text { Identified } \\
\text { by Gram Stain }\end{array}$ & $\begin{array}{c}\text { Culture } \\
\text { Positive }\end{array}$ & $\begin{array}{c}\text { Type of } \\
\text { Bacteria }\end{array}$ \\
\hline 20 & $8(40 \%)$ & $12(60 \%)$ & $\begin{array}{c}\text { Gram positive } 8 \\
(66.6 \%) \\
\text { Gram negative } 4 \\
(33.3 \%)\end{array}$ \\
\hline \multicolumn{3}{|c|}{ Table 10. Comparison of Gram Stain and } \\
Culture of Mucoid Sputum
\end{tabular}




\begin{tabular}{|c|c|c|c|}
\hline Total No. & $\begin{array}{c}\text { Bacteria } \\
\text { Identified by } \\
\text { Gram Stain }\end{array}$ & $\begin{array}{c}\text { Culture } \\
\text { Positive }\end{array}$ & $\begin{array}{c}\text { Type of } \\
\text { Bacteria }\end{array}$ \\
\hline 80 & $68(85 \%)$ & $80(100 \%)$ & $\begin{array}{c}\text { Gram positive } 52(65 \%) \\
\text { Gram negative } 28(33.3 \%)\end{array}$ \\
\hline \multicolumn{2}{|c|}{ Table 11. Comparison of Gram Stain and Culture of } \\
Mucopurulent Sputum
\end{tabular}

\begin{tabular}{|c|c|c|}
\hline Bacteria & Number & Percentage (\%) \\
\hline Streptococcus pneumoniae & 28 & 28 \\
\hline Klebsiella pneumoniae & 20 & 20 \\
\hline$\beta$-Haemolytic Streptococci & 20 & 20 \\
\hline Staphylococcus aureus & 12 & 12 \\
\hline Pseudomonas aeruginosa & 8 & 8 \\
\hline $\begin{array}{l}\text { E. coli } \\
\end{array}$ & 4 & 4 \\
\hline
\end{tabular}

Bacteria isolated in the sputum culture antibiogram (sensitivity pattern) of the bacteria isolated in the sputum culture is shown in the table.

\begin{tabular}{|c|c|c|c|}
\hline \multirow{2}{*}{$\begin{array}{c}\text { Antimicrobial } \\
\text { Agent }\end{array}$} & \multirow{2}{*}{\begin{tabular}{|c|} 
Drug Disc \\
Concentration \\
(mcg)
\end{tabular}} & \multicolumn{2}{|c|}{ Number of Isolates \% } \\
\hline & & Resistant & Susceptible \\
\hline \multicolumn{4}{|c|}{$\begin{array}{c}\text { Streptococcus } \\
\text { Pneumoniae }(n=28)\end{array}$} \\
\hline Ampicillin & 10 & 20 & 8 \\
\hline Ceftriaxone & 30 & 18 & 10 \\
\hline Tetracycline & 30 & 12 & 16 \\
\hline Gentamycin & 10 & 10 & 18 \\
\hline Amikacin & 30 & 2 & 26 \\
\hline Levofloxacin & 5 & 1 & 27 \\
\hline \multicolumn{4}{|c|}{$\begin{array}{l}\text { Klebsiella pneumonia } \\
(\mathrm{n}=20)\end{array}$} \\
\hline \begin{tabular}{|c|} 
Ampicillin \\
\end{tabular} & 10 & 20 & 00 \\
\hline Ceftriaxone & 30 & 08 & 12 \\
\hline Tetracycline & 30 & 11 & 09 \\
\hline Gentamycin & 10 & 06 & 14 \\
\hline Amikacin & 30 & 1 & 19 \\
\hline Levofloxacin & 5 & 1 & 19 \\
\hline \multicolumn{4}{|l|}{$\begin{array}{c}\beta \text {-Haemolytic } \\
\text { Streptococci } \\
(n=20)\end{array}$} \\
\hline Ampicillin & 10 & 16 & 04 \\
\hline Ceftriaxone & 30 & 12 & 08 \\
\hline Tetracycline & 30 & 15 & 05 \\
\hline Gentamycin & 10 & 7 & 13 \\
\hline Amikacin & 30 & 3 & 17 \\
\hline Levofloxacin & 5 & 0 & 20 \\
\hline \multicolumn{4}{|c|}{$\begin{array}{c}\text { Staphylococcus } \\
\text { aureus } \\
(\mathrm{n}=12)\end{array}$} \\
\hline Ampicillin & 10 & 12 & 00 \\
\hline Ceftriaxone & 30 & 08 & 04 \\
\hline Tetracycline & 30 & 07 & 05 \\
\hline Gentamycin & 10 & 02 & 10 \\
\hline Amikacin & 30 & 02 & 10 \\
\hline Levofloxacin & 5 & 1 & 11 \\
\hline $\begin{array}{c}\text { Pseudomonas } \\
\text { Aeruginosa }\end{array}$ & & & \\
\hline
\end{tabular}

\begin{tabular}{|c|c|c|c|}
\hline (n = 8) & & & \\
\hline Ampicillin & 10 & 08 & 00 \\
\hline Ceftriaxone & 30 & 08 & 00 \\
\hline Tetracycline & 30 & 02 & 06 \\
\hline Gentamycin & 10 & 01 & 07 \\
\hline Amikacin & 30 & 01 & 07 \\
\hline Levofloxacin & 5 & 00 & 08 \\
\hline E. coli (n = 4) & & & \\
\hline Ampicillin & 10 & 04 & 00 \\
\hline Ceftriaxone & 30 & 02 & 02 \\
\hline Tetracycline & 30 & 03 & 01 \\
\hline Gentamycin & 10 & 02 & 02 \\
\hline Amikacin & 30 & 00 & 04 \\
\hline Levofloxacin & 5 & 01 & 03 \\
\hline Table 13. Antibiogram of the Bacteria Isolated \\
\hline \multicolumn{4}{|c|}{ in Sputum Culture } \\
\hline
\end{tabular}

\begin{tabular}{|c|c|c|c|}
\hline $\begin{array}{c}\text { Age } \\
\text { (Years) }\end{array}$ & \multicolumn{3}{|c|}{ Clinical Outcome } \\
\hline & $\begin{array}{c}\text { Mean } \\
\text { Duration of } \\
\text { Stay (Days) }\end{array}$ & Deaths & $\begin{array}{c}\text { Discharge with } \\
\text { Home Oxygen } \\
\text { Therapy }\end{array}$ \\
\hline $31-40$ & 6 & - & \\
\hline $41-50$ & 7 & - & \\
\hline $51-60$ & 12 & - & 3 \\
\hline $61-70$ & 10 & - & 3 \\
\hline $71-80$ & 15 & - & \\
\hline \multicolumn{3}{|c|}{ Table 14. Clinical Outcome in Relation to Age } \\
\hline
\end{tabular}

The average length of stay in the hospital was about 10 days. Length of stay increased with age. There is no mortality in our study. Only $6(6 \%)$ patients were discharged with advice of home oxygen therapy.

We compared the clinical response of the study group with a control group of 20 patients who are also previously diagnosed with COPD now presented with clinical picture of acute exacerbation. The control group patients have been subjected to laboratory tests and were given empirical treatment without any sputum examination. The response is tabulated as under.

\begin{tabular}{|c|c|c|c|}
\hline Group & Fever & $\begin{array}{c}\text { Sputum } \\
\text { Production }\end{array}$ & Breathlessness \\
\hline $\begin{array}{c}\text { Study Group } \\
(100)\end{array}$ & $5-7$ days & 7 - 10 days & $4-5$ days \\
\hline $\begin{array}{c}\text { Control Group } \\
(20)\end{array}$ & $\begin{array}{c}10-12 \\
\text { days }\end{array}$ & $14-18$ days & 7 - 10 days \\
\hline \multicolumn{4}{|c|}{ Table 15. Symptomatology Distribution } \\
\hline
\end{tabular}

\section{Comparison with other Studies}

\begin{tabular}{|c|c|c|}
\hline Study & Year & Mean Age (Years) \\
\hline R.I.M. El Korashy et al & 2012 & 62.6 \\
\hline Saikat Basu et al(6) & 2012 & $54.88+8.82$ \\
\hline White et al(7) & 2003 & 52 years \\
\hline Shahnawaz A et al(8) & 2003 & $59.42+10.59$ \\
\hline Present Study & $2014-2015$ & 56.8 \\
\hline
\end{tabular}




\begin{tabular}{|c|c|c|}
\hline Study & Year & $\begin{array}{c}\text { Male-to- } \\
\text { Female Ratio }\end{array}$ \\
\hline Saikat Basu et al(6) & 2012 & $3.2: 1$ \\
\hline Fanny WS et al & 2005 & $3.7: 1$ \\
\hline Xiuqing Ma et al & $2013-2014$ & $1.83: 1$ \\
\hline Xue-Jun Li et al & $2007-2008$ & $2.48: 1$ \\
\hline Khaled Eid Sobhy et al & $2010-2013$ & $10: 1$ \\
\hline R.I.M. El Korashy et al & 2013 & $12.5: 1$ \\
\hline Levent Erkan et al & $1999-2002$ & $17.75: 1$ \\
\hline Present Study & $2014-2015$ & 15.66:1 \\
\hline \multicolumn{3}{|c|}{ Table 17. Comparison of Male-to-Female Ratio } \\
\hline
\end{tabular}

\begin{tabular}{|c|c|c|c|}
\hline Author & Year & $\begin{array}{c}\text { No. of } \\
\text { Patients }\end{array}$ & $\begin{array}{l}\text { Percentage of } \\
\text { Patients with } \\
\text { Positive Results }\end{array}$ \\
\hline Vesna Cukic & 2012 & 75 & $31 \%$ \\
\hline $\begin{array}{l}\text { Anand K Patel } \\
\text { et al }\end{array}$ & $\begin{array}{c}2011- \\
2012\end{array}$ & 50 & $82 \%$ \\
\hline $\begin{array}{l}\text { Mandira Varma } \\
\text { Basil et al }\end{array}$ & $\begin{array}{l}2004- \\
2006\end{array}$ & 100 & $16 \%$ \\
\hline Fanny WS & 2005 & 329 & $37.8 \%$ \\
\hline Luigi et al & 2004 & 581 & $90.7 \%$ \\
\hline Roche et al & 2003 & 118 & $59 \%$ \\
\hline Monso et al & 2003 & 90 & $43.3 \%$ \\
\hline White et al(7) & 2003 & 54 & $88.88 \%$ \\
\hline Pela et al & 1998 & 40 & $84 \%$ \\
\hline Present Study & $\begin{array}{l}2014- \\
2015\end{array}$ & 100 & $92 \%$ \\
\hline \multicolumn{4}{|c|}{$\begin{array}{c}\text { Table 18. Comparison of Percentage of Patients with } \\
\text { Positive Sputum Culture }\end{array}$} \\
\hline
\end{tabular}

\begin{tabular}{|c|c|c|}
\hline Study & Year & $\begin{array}{l}\text { Most Common Bacteria } \\
\text { Isolated }\end{array}$ \\
\hline Vesna Cukic & 2012 & Streptococcus pneumoniae \\
\hline Anand K Patel et al & $2011-12$ & Streptococcus pneumoniae \\
\hline Saikat Basu et al & 2012 & Klebsiella pneumoniae \\
\hline Shahnawaz A et a & 2003 & Pseudomonas aeruginosa \\
\hline White et al (7) & 2003 & Haemophilus influenzae \\
\hline Fanny WS et al & 2005 & Haemophilus influenzae \\
\hline Xiuqing Ma et al & $2013-14$ & Klebsiella pneumoniae \\
\hline Xue-Jun Li et al & $2007-08$ & Pseudomonas aeruginosa \\
\hline $\begin{array}{c}\text { Khaled Eid Sobhy } \\
\text { et al }\end{array}$ & $2010-13$ & Klebsiella pneumoniae \\
\hline $\begin{array}{l}\text { R.I.M. El Korashy } \\
\text { et al }\end{array}$ & $2012-13$ & Pseudomonas aeruginosa \\
\hline $\begin{array}{l}\text { Levent Erkan } \\
\text { et al }\end{array}$ & $\begin{array}{c}1999- \\
2002\end{array}$ & Haemophilus influenzae \\
\hline $\begin{array}{l}\text { Mandira Varma } \\
\text { Basil et al }(9)\end{array}$ & 2004-06 & Streptococcus pneumoniae \\
\hline Luigi et al & 2004 & Streptococcus pneumoniae \\
\hline N Arora et al(10) & 2001 & Streptococcus pneumoniae \\
\hline Saira Furqan et al & $2009-10$ & Streptococcus pneumoniae \\
\hline $\begin{array}{c}\text { Gerard Rakesh } \\
\text { et al(11) }\end{array}$ & 2013 & Streptococcus pneumoniae \\
\hline Pela et al & 1998 & Streptococcus pneumoniae \\
\hline Present study & 2014-15 & Streptococcus pneumoniae \\
\hline \multicolumn{3}{|c|}{$\begin{array}{c}\text { Table 19. Comparison of Most Common Bacteria Isolated } \\
\text { in Sputum Culture }\end{array}$} \\
\hline
\end{tabular}

\begin{tabular}{|c|c|c|}
\hline Study & Year & Most Effective Antibiotic \\
\hline Xiuqing Ma et al & $2013-14$ & Tigecycline \\
\hline Gerard Rakesh et al(11) & 2013 & Amikacin \\
\hline R.I.M. El Korashy et al & $2012-13$ & Imipenem \\
\hline Saikat Basu et al(6) & 2012 & Amikacin \\
\hline Khaled Eid Sobhy et al & $2010-13$ & Imipenem \\
\hline Madhavi S et al & 2011-2012 & Amikacin \\
\hline Saira Furqan et al & $2009-10$ & Levofloxacin \\
\hline Xue-Jun Li et al & $2007-08$ & Levofloxacin \\
\hline Shahnawaz A et al(8) & 2003 & Levofloxacin, Amikacin \\
\hline L. Davis et al(12) & 2001 & Co-Amoxiclav \\
\hline Levent Erkan et al & 1999-2002 & Ciprofloxacin \\
\hline Present Study & $2014-15$ & Levofloxacin, Amikacin \\
\hline \multicolumn{3}{|c|}{ Table 20. Comparison of Most Effective Antibiotic } \\
\hline
\end{tabular}

\section{Summary}

1. Majority of patients are in the age group of $39-80$ years.

2. Out of 100 people, $94 \%$ are males and $6 \%$ are females.

3. Most common presenting symptoms are cough (100\%) and expectoration $(100 \%)$ followed by breathlessness (95\%).

4. Out of 100 people, $64(64 \%)$ patients are current smokers, 28 (28\%) are ex-smokers and 8 were nonsmokers.

5. The most common type of sputum obtained is mucopurulent in $80(80 \%)$ patients followed by mucoid in $20(20 \%)$.

6. Mucopurulent sputum has been seen in $80(80 \%)$ cases, in which Gram's stain identified bacteria in 68 (85\%) cases and culture isolated bacteria in all $80(100 \%)$ cases.

7. Mucoid sputum has been seen in 20 cases, Gram's stain identified bacteria in $8(20 \%)$ cases and culture is positive in $12(60 \%)$ cases.

8. The commonest bacteria isolated in sputum culture is Streptococcus pneumoniae (28\%) followed by Klebsiella pneumoniae (20\%).

9. Bacterial pathogens isolated in our study are more sensitive to levofloxacin (95\%) followed by amikacin (91\%).

10. The clinical response in the case study group is early, predictive and early as compared to the control group.

\section{DISCUSSION}

In our study, the study group consists of 100 patients. The mean age of patients in our study is 56.8 years. This is comparable to studies undertaken by L. Davis et al(12) (50 years), White et al(7) (52 years), Fanny et al(10) $(74.4+8.3$ years), N Arora et al(10) $(47.36+11.25$ years), Shahnawaz A et al.(8) Most of the subjects (36\%) in our study falls in the age group of 51 - 60 years, which is comparable to studies undertaken by $\mathrm{N}$ Arora et al,(10) in which $67 \%$ of people are in the age group of 50 - 60 years, Saikat Basu et al(6) in which $38 \%$ of people falls in the age group of 55 - 65 years and Gerard Rakesh et al (54), in which $43 \%$ of the subjects falls in the age group was 50 - 55 years.

\section{Marc Miravitlles}

1999 from Spain culture sputum samples from 91 patients and isolated Haemophilus influenzae 20 cases, Pseudomonas aeruginosa 14 cases and Streptococcus pneumoniae 9 cases, Moraxella catarrhalis 8 cases. The other being gram negative 
bacteria 7 cases.(13)

Breathlessness on exertion, sometimes accompanied by wheeze and cough, which is often but not invariably productive are the characteristic symptoms of COPD. Reversibility tests are important in COPD to distinguish those patients with marked reversibility who have underlying asthma, because of FEV1 after bronchodilator is the best predictor of survival.(14) Questioning usually reveals the presence of a 'smoker's cough' with the production of small amounts (usually $<60 \mathrm{~mL}$ ) of mucoid sputum, often occurring predominantly in the morning for many years.

The major presenting symptoms in our study are worsening of cough and expectoration in $100 \%$ of the patients, $95 \%$ of the patients are presented with worsening of breathlessness, $52 \%$ of people have fever and $24 \%$ of patients have chest pain on the day of admission. This was comparable to the study undertaken by Mandira Varma Basil et al,(9) in which $90 \%$ of people presented with worsening of breathlessness.

Chronic Obstructive Pulmonary Disease (COPD) is the fourth leading cause of death in the world and expected to be the third leading cause of death by year 2030, represents an important public health challenge that is both preventable and treatable.(15) Globally, the COPD burden is projected to increase in coming decades because of continued exposure to COPD risk factors and aging of the population.(16)

\section{CONCLUSIONS AND PROPOSALS}

1. Our study concludes that the AECOPD patients suffer from deterioration of general condition and respiratory function, which leads to increased morbidity. Many working days are lost and there is a definite deterioration of quality of life index. Moreover, as the patient is elderly the attendants also must lose their active working days to take care of the sick.

2. The clinical response must be early and effective. This must be re-evaluated in a demographic area periodically by the health care personnel.

3. The microbiological study with culture specific antibiotic is the best, though it takes a prolonged time of one week. The bedside Gram staining examination of sputum may be offered as an equally specific test.

4. There may be some alterations in the type of bacteria that cause AECOPD and their pharmacological response at the community level.

5. Our study offers a reference for the spectrum of antibiotics that are most effective, hence will be of high value both at the teaching hospital and rural healthcare facilities.

6. We propose such studies in the referral teaching hospital as multidisciplinary care is available to be done periodically to provide vital information regarding the pattern of respiratory diseases.

\section{REFERENCES}

[1] Celli BR, Barnes PJ. Exacerbations of chronic obstructive pulmonary disease. Eur Respir J 2007;29(6):1224-38. Review. Erratum in: Eur Respir J 2007 Aug; 30(2): 4017.

[2] Leuppi JD, Schuetz P, Bingisser R, et al. Short-term vs conventional glucocorticoid therapy in acute exacerbations of chronic obstructive pulmonary disease: the REDUCE randomized clinical trial. JAMA 2013;309(21):2223-31.

[3] Grohskopf LA, Sokolow LZ, Olsen SJ, et al. Prevention and control of influenza with vaccines: recommendations of the Advisory Committee on Immunization Practices, United States, 2015-16 influenza season. MMWR Morb Mortal Wkly Rep 2015;64(30):818-25.

[4] Rabe KF. Update on roflumilast, a phosphodiesterase 4 inhibitor for the treatment of chronic obstructive pulmonary disease. Br J Pharmacol 2011;163(1):53-67.

[5] Singanayagam A, Schembri S, Chalmers JD. Predictors of mortality in hospitalized adults with acute exacerbation of chronic obstructive pulmonary disease. Ann Am Thorac Soc 2013;10(2):81-9.

[6] Basu S, Mukherjee S, Samanta A. Epidemiological study of bacterial microbiology in AECOPD patients of Kolkata, India. Asian J Pharm Clin Res 2013;6(1):112-6.

[7] White AJ, Gompertz S, Bayley DL, et al. Resolution of bacterial inflammation is related to bacterial eradication following treatment of exacerbation of chronic bronchitis. Thorax 2003;58(8):680-5.

[8] Shahnawaz A, Saleem SM, Bhat MALSST, et al. Bacteriological profile in acute exacerbation of chronic obstructive pulmonary disease (COPD). JK-Practitioner 2003;10(3):185-7.

[9] Varma-Basil M, Dwivedi SK, Kumar K, et al. Role of Mycoplasma pneumoniae infection in acute exacerbations of chronic obstructive pulmonary disease. J Med Microbiol 2009;58(Pt 3):322-6.

[10] Arora N, Daga MK, Mahajan R, et al. Microbial pattern of acute infective exacerbation of chronic obstructive airway disease in a hospital based study. Indian J Chest Dis Allied Sci 2001;43(3):157-62.

[11] Rakesh G, Kasturi T, Yuvarajan S. Bacterial agents causing acute exacerbations in Chronic Obstructive Pulmonary Disease (COPD) patients, their antibiograms to Extended Spectrum Beta-Lactamases (ESBL) production in a tertiary care hosp, India. Int J Curr Microbiol App Sci 2013;2(11):273-82.

[12] Davis L, Hadcroft J, Mutton K, et al. Anti-microbial management of acute exacerbation of chronic airflow limitation. Q J Med 2001;94(7):373-8.

[13] Miravitlles M, Espinosa C, Fernandez-Laso E, et al. Relationship between bacterial flora in sputum and functional impairment in patients with acute exacerbation of COPD. Study group of bacterial infection in COPD. Chest 1999;116(1):40-6.

[14] Celli BR. The importance of spirometry in COPD and Asthma: effect on approach to management. Chest 2000;117(2 Suppl):15S-19S.

[15] World Health Report. Geneva; World Health Organisation, $2000 . \quad$ http:// www.who.int/whr/2000/en/statistics.htm; 2000: accessed on $18^{\text {th }}$ April 2014.

[16] Lopez AD, Shibuya K, Rao C, et al. Chronic obstructive pulmonary disease: current burden and future projections. Eur Respir J 2006;27(2):397-412. 